\title{
nature
}

\section{Dutch cuts ahead}

The new government of the Netherlands should reverse rather than exacerbate its declining support for basic science - a message reinforced by the OECD.

A s science policy makers in the Northern Hemisphere head for the summer beaches, few are likely to take with them a weighty report, Technology, Productivity and Job Creation: Best Policy Practices, recently published by the Organisation for Economic Co-operation and Development (OECD) in Paris. But the report's message should be remembered on their return. For it is a timely reminder that countries that have developed a healthy knowledge-based economy are those that have combined a vibrant science base with the broader reforms needed to ensure that both research funds and scientific results are used effectively.

The Dutch coalition government of left, centre and right, reelected to power in May, has secured much of the second, but is in danger of losing sight of the first. In its four previous years in office, the government achieved admirable economic results, reducing the public deficit substantially while holding inflation at 2 per cent and unemployment at 5.5 per cent. Partly as a result, the economy is growing at 3.5 per cent. Its record on research gives less to smile about, however, and the government is now about to pass up an opportunity to use the economic windfalls of the past four years to reverse a sharp fall in research funding over the past decade.

On the contrary, the situation is about to get much worse, with significant cuts planned in science across the research organizations and universities (see page 405). Worryingly, the government seems to have decided that investment should go rather to a handful of applied research and technological infrastructure projects. In themselves, such projects may be worthwhile. The mistake would be to fund them at the expense of fundamental research. The government has repeatedly declared a commitment to science, and has been hyperactive in its reform of the research system to improve cost-effectiveness, concentrate resources and increase competition among researchers. But with the forthcoming cuts, the plethora of reforms will be seen as a rearrangement of deckchairs on a sinking ship.

It could be that negotiations between coalition partners have, in effect, elbowed science aside. But Jo Ritzen, the outgoing science minister and a former professor at Erasmus University, must share some of the blame: the record of the past few years alone testifies to a lack of political clout. It can only be hoped that his successor - expected to be the Liberal Party member Louk Hermans - will be more successful in mobilizing support and significantly enhancing the government's perception of science's importance.

The Netherlands is one of only a handful of OECD countries identified in that organization's report as demonstrating 'best policy practice' in its handling of the science base. Some recent changes, such as the regrouping of university research schools, have brought their own discomforts and problems. But the general thrust of the reforms has been positive. It would be a disaster for Dutch science — and, in the long term, for its economy — if they were now to be undermined by ill-considered political penny-pinching.

\section{A word in your ear}

\section{As the conference season approaches, it is time to reflect on the negative effects of ill-prepared presentations.}

$(1$ onference presentations that leave an audience dumbfounded, confused, exasperated or just plain bored are, unfortunately, a fact of life. A talent for conveying information orally and for well-judged visual presentation is not bestowed on all, while some scientific topics struggle more than others under the necessary weight of details that are as essential as they are overwhelming or intricate. Harder to accept, however, is that some individuals can sustain a substantial career in research without mastering even the basics of public presentation - and continue to ply the conference circuit regardless. Communication skills seem to count for little in comparison with reputation when it comes to invitations to speak.

This is surely disrespectful to audiences that have, after all, often paid considerable registration fees and travelling costs for the privilege of listening. A lack of clarity in the published literature is frequently bemoaned; but at least a reader has the opportunity to pore over a printed text as long as patience allows, slowly dismantling difficult sentences or equations, and digesting complex data. An oral presentation, in contrast, is a one-shot affair. When slides or overheads stuffed with detail are flashed up for barely an instant, when objectives are not clearly stated at the outset, or when highly specialized concepts are assumed to be general knowledge, one might as well have stayed at home and waited for the paper to appear in print.

Such frustrations are a symptom of the low importance that researchers often attach to the clear transmission of ideas, much as excellence in teaching counts for little when it comes to seeking academic tenure. For oral presentation is, in the end, a form of theatre (if all too often of a breed that Ionesco would have relished). The appropriate skills do not necessarily fall into place as a matter of course; they need to be nurtured (see, for example, the excellent Public Speaking for Scientists and Engineers by P. Kenny; IOP Publishing via www.iop.org). This does not imply that excellent presentations need to be flashy or technologically accomplished performances. Nor need it place at a disadvantage those for whom English is not their first language: clear organization and visual presentation do not depend on that.

Neither is it simply a matter of teaching young researchers the right technique; indeed, presentations by newcomers are usually commendably clear precisely because inexperience stimulates more conscientious preparation. Rather, conference organizers should think twice before inflicting on their attendees speakers who are known to show little sympathy for the needs of a broad audience. Better, surely, to interpret their ineptness as a sign of discomfort and to release them from the obligation for their sake as well as for that of everybody else. 